\title{
PRKCA-Binding Protein
}

National Cancer Institute

\section{Source}

National Cancer Institute. PRKCA-Binding Protein. NCI Thesaurus. Code C134684.

PRKCA-binding protein (415 aa, $47 \mathrm{kDa}$ ) is encoded by the human PICK1 gene. This protein is involved in the modulation of receptor signaling, localization and internalization. 